\title{
Serendipity and the discovery of foods
}

\author{
Tam-Tri Le \\ Centre for Interdisciplinary Social Research \\ Phenikaa University, Hanoi, Vietnam
}

2022 January 16

OSF Preprints

Serendipity is a crucial factor in innovation (Napier \& Vuong, 2013, Q.-H. Vuong et al., 2022), but it is not only present in the realms of business and science. Our ancestors as well as modern humans also discovered foods from serendipity. This information process of innovation includes the Mindsponge mechanism (Vuong \& Napier, 2015) and the 3D principles of creativity (Vuong \& Napier, 2014). But unlike the cost in research (Vuong, 2018), in our early human societies, the cost there is the matter of physiological survival.

Regarding the big questions on food for early humans, they should have been "what are edible?", "what are more nutritious?", and "what can be mass-produced?", in that order. Studies on the origin of agriculture revealed that ancient humans had a very long history of establishing their grain-based diets (Choi, 2016). About 2.5 million years ago (Lower Paleolithic), humans gathered random plants. About 300 thousand years ago (Middle Paleolithic), humans started to focus on more nutritious plants; and the use of edible plants became more sophisticated about 50 thousand years ago (Upper Paleolithic). Various types of grass seeds intentionally collected from wild grasses were the staple foods of the Chinese about 30 thousand years ago (Wang, Lu, Zhang, $\mathrm{He}, \&$ Huan, 2016). The transition from foraging to grain agriculture shared similarities between cultivating rice and millet in China and wheat and barley in West Asia. Wild grass seeds were found to be used as staple foods in the Israel region 23 thousand years ago (Weiss, Kislev, Simchoni, \& Nadel, 2004). In this early time, humans needed to be able to notice edible and nutritious items among a lot of random objects they encountered in the wild. The ability to notice valuable information from the natural environment was a matter of life and death when sufficient food supply was a major daily concern.

While survival motives in terms of sustenance are not always so raw and direct - especially in the modern era, the skills for recognizing valuable information from one's surroundings have led to delightful discoveries in food and cuisine throughout human history. Some popular foods we are familiar with today are the results of interesting serendipity moments in the past. For example, humans started to consume cheese more than 4000 years ago, together with the story of an Arabian merchant who accidentally made cheese while going across a desert as he stored milk inside a sheep's stomach (containing rennet) and discovered the delicious curd after a while in the hot weather (International Dairy Foods Association, 2021). Quite similarly, yogurt - a fermented milk product used in many different regions across the globe since thousands of years ago - was discovered by herdsmen who kept milk in bags made from animal intestines (Fisberg 
\& Machado, 2015). Other fermented products such as beer and pickles are also often believed to have been accidentally discovered. Regarding the origin of coffee, there was a story about a goat herder in Ethiopia who observed that goats eating the berries of a certain tree became energetic and could not sleep; he later shared his findings with the local monastery and made a drink from those berries, which later led to the start of coffee cultivation on the Arabian Peninsula in the $15^{\text {th }}$ century (National Coffee Association USA, 2021). Some ancient legends also suggest that tofu was made accidentally in China during the Han dynasty before later becoming a popular food across many East and Southeast Asian countries. In recent times, by chance, we have also created several popular modern foods such as popsicles, potato chips, corn flakes, and chocolate chip cookies.

Update: More detailed discussions in the full book "A New Theory of Serendipity: Nature, Emergence and Mechanism" (see References).

\section{Acknowledgement}

I would like to thank my mentor Dr. Quan-Hoang Vuong and my friend Minh-Hoang Nguyen for the insights.

\section{References}

Choi, C. (2016). Ancient Chinese may have cultivated grass seeds 30,000 years ago. Retrieved from https://blog.pnas.org/2016/03/journal-club-ancient-chinese-may-have-cultivated-grass-seeds30000-years-ago/

Fisberg, M., \& Machado, R. (2015). History of yogurt and current patterns of consumption. Nutrition Reviews, 73(suppl_1), 4-7. doi:10.1093/nutrit/nuv020

International Dairy Foods Association. (2021). History of Cheese. Retrieved from https://www.idfa.org/news-views/media-kits/cheese/history-of-cheese

Napier, N., \& Vuong, Q. H. (2013). Serendipity as a Strategic Advantage? In T. Wilkinson (Ed.), Strategic Management in the 21st Century (pp. 175-199). Westport, CT: Praeger/ABC-Clio.

National Coffee Association USA. (2021). The History of Coffee. Retrieved from https://www.ncausa.org/about-coffee/history-of-coffee

Vuong, Q. H., \& Napier, N. K. (2014). Making creativity: the value of multiple filters in the innovation process. International Journal of Transitions and Innovation Systems, 3(4), 294-327. doi:10.1504/IJTIS.2014.068306

Vuong, Q. H., \& Napier, N. K. (2015). Acculturation and global mindsponge: An emerging market perspective. International Journal of Intercultural Relations, 49, 354-367. doi:10.1016/j.ijintrel.2015.06.003

Vuong, Q.-H. (2018). The (ir)rational consideration of the cost of science in transition economies. Nature Human Behaviour, 2(1), 5. doi:10.1038/s41562-017-0281-4 
Vuong, Q.-H., et al. (2022). Covid-19 vaccines production and societal immunization under the serendipity-mindsponge-3D knowledge management theory and conceptual framework. Humanities and Social Sciences Communications, 9, forthcoming.

Wang, C., Lu, H., Zhang, J., He, K., \& Huan, X. (2016). Macro-Process of Past Plant Subsistence from the Upper Paleolithic to Middle Neolithic in China: A Quantitative Analysis of MultiArchaeobotanical Data. PloS one, 11(2), e0148136. doi:10.1371/journal.pone.0148136

Weiss, E., Kislev, M. E., Simchoni, O., \& Nadel, D. (2004). Small-Grained Wild Grasses as Staple Food at the 23 000-Year-Old Site of Ohalo II, Israel. Economic Botany, 58, S125-S134.

Quan-Hoang Vuong. (2022). A New Theory of Serendipity: Nature, Emergence and Mechanism. Berlin, Germany: De Gruyter. 